IZA DP No. 5111

The Productivity Effects of Profit Sharing, Employee Ownership, Stock Option and Team Incentive Plans:

Evidence from Korean Panel Data

Takao Kato

Ju Ho Lee

Jang-Soo Ryu

August 2010 


\title{
The Productivity Effects of Profit Sharing, Employee Ownership, Stock Option and Team Incentive Plans: Evidence from Korean Panel Data
}

\author{
Takao Kato \\ Colgate University, CJEB (Columbia), \\ TCER (Tokyo), CCP (Aarhus) and IZA \\ Ju Ho Lee \\ Korea Development Institute \\ Jang-Soo Ryu \\ Pukyong National University \\ Discussion Paper No. 5111 \\ August 2010 \\ IZA \\ P.O. Box 7240 \\ 53072 Bonn \\ Germany \\ Phone: +49-228-3894-0 \\ Fax: +49-228-3894-180 \\ E-mail: iza@iza.org
}

Any opinions expressed here are those of the author(s) and not those of IZA. Research published in this series may include views on policy, but the institute itself takes no institutional policy positions.

The Institute for the Study of Labor (IZA) in Bonn is a local and virtual international research center and a place of communication between science, politics and business. IZA is an independent nonprofit organization supported by Deutsche Post Foundation. The center is associated with the University of Bonn and offers a stimulating research environment through its international network, workshops and conferences, data service, project support, research visits and doctoral program. IZA engages in (i) original and internationally competitive research in all fields of labor economics, (ii) development of policy concepts, and (iii) dissemination of research results and concepts to the interested public.

IZA Discussion Papers often represent preliminary work and are circulated to encourage discussion. Citation of such a paper should account for its provisional character. A revised version may be available directly from the author. 


\section{ABSTRACT \\ The Productivity Effects of Profit Sharing, Employee Ownership, Stock Option and Team Incentive Plans: Evidence from Korean Panel Data}

We report the first results for Korean firms on the incidence, diffusion, scope and effects of diverse employee financial participation schemes, such as Profit Sharing Plans (PSPs), Employee Stock Ownership Plans (ESOPs), Stock Option Plans (SOPs) and Team Incentive Plans (TIPS). In do doing, we assemble important new panel data by merging data from a survey of all Korean firms listed on Korean Stock Exchange which enjoys an unusually high response rate of 60 percent with accounting data from their corporate proxy statements. Our estimated fixed effect models of production functions reveal consistently that the introduction of a PSP or a TIP will lead to a significant increase in productivity (about 10 percent) whereas no such evidence found for ESOPs or SOPs. We also find that the productivity payoff appears to be more long-lasting for PSPS than for TIPS. Finally, our fixed-effect estimates suggest that PSPS and TIPS tend to be substitutes rather than complements in their productivity effects.

JEL Classification: $\quad$ M52, J33, J24, J53, 053

Keywords: profit sharing, employee stock ownership, team incentive, stock option, productivity, Korea

Corresponding author:

Takao Kato

Department of Economics

Colgate University

13 Oak Drive

Hamilton, NY 13346

USA

E-mail: tkato@colgate.edu

\footnotetext{
* We are grateful for support from the Korea Labor Institute. An earlier version of the paper was written while Kato was Distinguished Visiting Professor at KDI School of Public Policy and Management. Kato is thankful for their hospitality. The paper has benefited from comments and suggestions from DongBae Kim, Sam-Su Kim, and Yong-Jin Ro. Jong-Kyu Lee provided excellent research assistance. Finally, we owe our great debt of gratitude to the HR managers, line supervisors and union officials of Korean companies who granted us the opportunities to interview them.
} 


\section{THE PRODUCTIVITY EFFECTS OF PROFIT SHARING, EMPLOYEE OWNERSHIP, STOCK OPTION AND TEAM INCENTIVE PLANS: Evidence from Korean Panel Data}

\section{Introduction}

Compensation systems have been shifting away rapidly from a fixed wage contractual payment basis in many nations around the world (Ben-Ner and Jones, 1995). Particularly prominent is the explosion in the use and interest in employee financial participation schemes, such as profit sharing, employee stock ownership, stock option, and team incentive (or gainsharing) plans. With the rising use and interest in such employee financial participation schemes, many studies have examined their effects on enterprise performance in industrialized countries. ${ }^{1}$ Most prior studies consider either Profit Sharing Plans (PSPs) in which at least part of the compensation for no executive employees is dependent on firm performance (typically profit) ${ }^{2}$ or Employee Stock Ownership Plans (ESOPs) through which the firm forms an ESOP trust consisting of its non-executive employees and promotes ownership of its own shares by the trust. ${ }^{3}$ Moreover, an increasing number of firms (in particular "New Economy" firms) are extending the use of Stock Option Plans (SOPs) to include non-executive employees in recent years. ${ }^{4}$ Finally, with the rising popularity of "High Performance Workplace Practices (notably self-directed teams)”, more firms are introducing TIPs (Team Incentive Plans) which makes at least part of the compensation for employees dependent on performance of the team or work group to which they belong. ${ }^{5}$

${ }^{1}$ For a survey of the literature on financial participation schemes, see for instance Kruse (1997) on employee stock ownership and Jones, Kato and Pliskin (1997) on profit sharing, gain sharing/team incentives. For a Meta-analysis of the literature, see Doucouliagos (1995). For a more theoretical survey of the literature, see Gibbons (1997) and Prendergast (1999). For more recent works, see the shared capitalism literature (see, for instance, Kruse, Blasi and Park, 2008 and Bryson and Freeman, 2008).

${ }^{2}$ For detailed discussion on the definition of PSPs, see Kruse (1993) and Jones, Kato and Pliskin (1997).

${ }^{3}$ See, for instance, Jones and Kato (1995), Blasi, Conte and Kruse (1996), and Kruse and Blasi

${ }^{4}$ See, for instance, Conyon and Freeman (2001) and Sesil and et al. (2003).

5 See, for example, Hamilton, Nickerson and Owan (2003), Jones and Kato (2007), and Jones, Kalmi, and Kauhanen (2009) for teams and TIPs. 
Outside of major industrialized countries, in particular NICs (Newly Industrialized Countries), however, research on the performance effects of such schemes is extremely limited. ${ }^{6}$ The paucity of systematic studies on employee financial participation schemes in NICs (in particular South Korea) is surprising considering the growing importance of such economies (e.g., South Korea is currently 12th largest economy in the world).

This paper provides much-needed rigorous evidence on the incidence, diffusion, scope and effects of various forms of financial participation schemes in South Korea. We do so by using a new comprehensive survey of publicly traded firms in South Korea, the Survey on Human Resource Management (SHRM). The survey was conducted by the Korea Labor Institute in August-September in 2000. The sample universe of the SHRM was all firms listed in Korea Stock Exchange (KSE) at the time of the survey (there were about 600 of them). The response rate was over $60 \%$ which compares very favorably to similar firm-level surveys conducted in the past in other industrialized countries. ${ }^{7}$ The unusually high response rate of the SHRM makes the Korean data particularly appealing.

${ }^{6}$ In the English-language literature we are aware of only one study which investigates the productivity effect of financial participation in NICs, i.e., Cin and Smith (2002) which provide cross-sectional estimates on the productivity effects of employee stock ownership plans in South Korea. Our study extends Cin and Smith (2002) in two important ways. First, we are able to assemble long panel data (10 years) which enable us to estimate fixed effect models and hence account for potentially serious omitted variable bias due to unobserved firm heterogeneity, such as managerial ability, which may be correlated with the adoption of financial participation schemes. Second, we are able to consider not only ESOPs but also other financial participation schemes, such as profit sharing, team incentives and stock option, and test whether there is any synergic relationship among schemes.

${ }^{7}$ Freeman, Kleiner and Ostroff (2000), one of better-known examples of work using firm-level survey data, used the Human Resource Practice Survey of member firms of the Society of Human Resource Management in the U.S. and the survey's response rate was $11 \%$. The Human Resource Management Survey of Japanese Firms conducted by Kato and Morishima (2002) received about 20\% of all Japanese firms listed in Japan's three major Stock Exchanges. In addition, in June of 1991, the Rengo Sogo Seikatsu Kaihatsu Kenkyu Jo (Rengo Research Institute of General Life Development) in Japan mailed their questionnaire asking questions on labor conditions and employee participation/involvement to 6,800 firms (including both public and private firms in Japan) and received usable responses from 689 firms (a response rate of 10\%). In June of 1989, the Japan Productivity Center mailed their questionnaire asking questions on HRMPs to 1030 firms in Japan and received usable responses from 203 firms (a response rate of 19.7\%). 
In the next section we begin with documenting the incidence, diffusion, and scope of Korean financial participation schemes using our new survey data. We then combine the survey data with the corporate proxy statement data base assembled by the KLCA (Korea Listed Companies Association to create for the first time a panel data set for over 200 Korean manufacturing firms that provides data on the use of a variety of financial participation schemes as well as value added, labor input and capital input over 1990-2000. The data are then used to estimate production functions with fixed effects, augmented by variables to capture the effects of these financial participation schemes.

We find consistently that the introduction of PSPs and TIPs, will lead to a significant increase in productivity (a little over 10 percent) whereas we find no such evidence for stock-based schemes, such as ESOPs and SOPs. We also find that the productivity payoff appears to be more long-lasting for PSPs than for TIPs. Finally, our fixed-effect estimates suggest that PSPs and TIPs tend to be substitutes rather than complements in their productivity effects.

The paper is organized as follows. In the next section, we document the incidence, diffusion and scope of employee financial participation schemes in South Korea. In Section II we offer general theoretical arguments for the productivity effects of such financial participation and argue that we expect strong productivity gains from PSPs and TIPs in Korea and somewhat weaker results for stock-based schemes such as ESOPs and SOPs. We then present evidence from our field research at two manufacturing firms in Korea which demonstrates vividly the strong use of PSPs and TIPs and the weak use or absence of stock-based schemes. Section III provides the basic empirical strategy and describes the data. In section IV we present our main empirical results, followed by a concluding section. 


\section{The Incidence, Diffusion and Scope of Korean Financial Participation Schemes}

As discussed above, employee financial participation comes in a variety of forms. Most prior studies investigate either Profit Sharing Plans (PSPs) or Employee Stock Ownership Plans (ESOPs), and lately researchers are beginning to study SOPs and TIPs. Fortunately, our Korean data (SHRM) provides information on all four schemes (PSPs, ESOPs, SOPs and TIPs) and thus grants us an unusual opportunity to examine all four schemes together. In particular, the data enable us to address systematically one of the most often discussed issues in the literature or whether some of these schemes are complements or substitutes. ${ }^{8}$

According to the SHRM, as shown in Table 1 and Figure 1, over 35 percent of publicly traded firms in South Korea had a PSP in 2000. The proportion of firms with a PSP was only 3 percent in early 1980s and grew steadily to 10 percent by early 1990s. A significant diffusion occurred during 1990s (in particular late 1990s) in large part due to governmental promotion of PSPs in the 1990s. Table 1 also shows that there is no discernable difference in the incidence of PSPs between manufacturing and non-manufacturing firms.

As shown in Figure 1, by mid 1980s, the proportion of firms that had an ESOP was less than 10 percent. In early 1990s, Korean government advocated ESOPs as a way to help firms obtain much needed capital for investment. The government, using informal channels as well as a tax incentive, encouraged firms to set up new ESOPs to accommodate employee investments in their stock. Perhaps partly due to this government initiative, the next decade was characterized by a rapid pace of diffusion of the institution, and over one half of firms came to have ESOPs by 2000 .

${ }^{8}$ See, for instance, Fitzroy and Kraft (1987); Weitzman and Kruse (1990); Levine and Tyson (1990); Jones and Pliskin (1991); Ben-Ner and Jones (1995); Kandel and Lazear (1992); Kruse (1993); Holmstrom and Milgrom (1994); Baker, Gibbons and Murphy (1994); Milgrom and Roberts (1995); Ichniowski, Shaw and Prennushi (1997), Helper (1998), Black and Lynch (2001, 2004), Kato and Morishima (2002), Eriksson (2003), Bayo-Moriones, et. al. (2003), Zwick (2004), DeVaro (2006), Jones, Kalmi and Kauhanen (2006), Heywood, Jirjahn, and Wei (2008). 
SOPs became legal in 1997 in South Korea. Since then, SOPs have been spreading among Korean firms rapidly and by 2000, 15 percent of firms reported to use such a plan.

Finally, according to the survey, as shown in Table 1 and Figure 1, only less than 1 percent of publicly traded firms used TIPs before the 1990's. In early 1990s the institution diffused steadily. The rapid diffusion took place after the Asian crisis. In 2000, almost one in four firms used TIPs. Again, the rapid diffusion of TIPs was in part due to public policy initiatives to respond to the Asian Crisis.

Table 2 shows the scope of each scheme (or how widely each scheme applies to the firm's labor force). The scope of Korean PSPs compares favorably to such schemes elsewhere. Thus, for Korean firms with PSPs, typically over $90 \%$ of employees are covered by a PSP whereas Kruse (1993) reports that nearly $80 \%$ of employees are covered by a PSP in the U.S. Furthermore, unlike the U.S., Korean PSPs rarely have separate plans for different divisions and occupations or for union and non-union members. This way, Korean PSPs are more similar to Japanese PSPs (Kato and Morishima, 2003). Nearly all Korean PSPs are cash plans, which is in sharp contrast to the U.S. where deferred plans are more popular (Kato and Morishima, 2003).

As shown in Table 2, about 30 percent of the labor force in firms with ESOPs actually participate in the plan. The figure is hardly trivial although still lower than in Japan and the U.S. (Jones and Kato, 1995). Furthermore, there is much attrition in U.S. ESOPs. This contrasts sharply with the situation in Korea (and Japan) where the rate of termination is negligible.

However, in Korea, recently employees were allowed to withdraw their shares only after one year of vesting (it used to be 7 years) and hence there are currently a significant number of ESOPs in Korea with no employee participation. Our data on ESOPs exclude those defunct ESOPs. ${ }^{9}$

9 This explains the difference in the estimated incidence of ESOPs between our study and Cin and Smith (2002). 
As shown in Table 2, Korean SOPs are fairly broad-based with 26 percent of all employees in firms with SOPs covered by the plan. Finally, as Table 2 shows, over 50 percent of employees in firms with TIPs are covered by such pay systems. The penetration of TIPs once introduced is quite high in Korea.

\section{Productivity Effects of Financial Participation Schemes: Hypotheses}

Generally formal economic theory is ambiguous as to the expected impact of employee financial participation schemes on productivity. ${ }^{10}$ Focusing on individual motivation and performance, however, several hypotheses predict positive productivity effects, of which the Goal Alignment Effects are perhaps most important. In addition, there are a few hypotheses concerning the complementarities and substitutabilities among employee financial participation schemes.

PSPs help align the interest of the firm with the interest of its workers by making pay for workers sensitive to firm performance (e.g., profitability). Similarly the positive productivity effects of ESOPs and SOPs stem from firm success being reflected in a higher price of its stock, and thus increased wealth for workers who own stock in the ESOP. As such, the interest of the firm is more aligned with the interest of its workers. TIPs also help the goal alignment between employees and their teams/work groups and foster team cooperation.

As shown in the previous section, considerably higher proportions of the labor force are covered by PSPs and TIPs than ESOPs and SOPs. Thus, we expect greater effects on enterprise level productivity of PSPs and TIPs as compared to ESOPs and SOPs. The relative importance of cash-based group incentive pay, such as PSPs and TIPs in Korean firms can be also demonstrated

\footnotetext{
${ }^{10}$ For reviews, see the essays in Blinder (1990) and Gibbons (1997).
} 
vividly by field research we conducted at two large manufacturing firms, Firm A and Firm B. ${ }^{11}$ Firm A is a large manufacturing firm with sales of over 20 trillion won and employment of over 50,000 workers world-wide (close to 30,000 in Korea) in 2003. Firm B is also a manufacturer with sales of over 7 billion won and employment of about 1,600 workers in 2003. Though considerably smaller than Firm A, Firm B is a leading manufacturer in terms of its market share in their products. Firm A is a publicly traded firm, listed on KSE (Korea Stock Exchange) whereas Firm B is privately owned. Both firms are unionized. ${ }^{12}$

Like many other Korean firms, each employee at Firm B receives a regular bonus which amounts to 8 months (or 800 percent) of his/her monthly base pay. As in the case of the bonus payment system in Japan, most Korean employees consider such regular bonuses part of their regular pay. Separate from regular bonus, both Firm A and Firm B provides all of its employees with PSP bonuses. Firm B has a longer history of PSPs than Firm A with Firm B's PSP in existence for at least ten years. It is broad-based with all employees covered by the same plan with one exception that a specific formulae is used to calculate the amount of PSP bonus for top management whereas no such formulae used for other employees. Thus, except for top management, the amount of PSP bonus is decided through collective bargaining between labor union and management at the end of each year. Both union and management understands that the amount of PSP bonus reflects firm performance although there is neither specific measure used to

${ }^{11}$ Our confidentiality agreements with both firms prohibit us from identifying the specific products they produce.

${ }^{12}$ Firm A is known for successful representative participation and labor-management cooperation through work councils and Firm B is famous for the use of self-directed teams. As such, they may not be representative of the population of Korean firms in terms of employee involvement and participation. The purpose of presenting field evidence here is to demonstrate the stronger use of cash-based incentive pay as compared to stock-based incentive schemes in Korean firms with successful employee involvement and labor-management cooperation. See Kato, Lee, Lee, and Ryu (2005) for a more detailed description of the case studies. 
gauge firm performance nor specific formulae used to calculate the amount of PSP bonus. When firm performand is weak, the amount of PSP bonus can be set to zero. In fact, at the Asian Crisis (1997 and 1998), employees at Firm B received no PSP bonus. Except for those two years, the amount of PSP bonus has been positive and on average amounts to about 2 months of monthly base pay.

Firm A introduced a new form of PSP in 2000 which applies to all employees. Unlike Firm B, Firm A uses a specific firm performance measure. As such, once a year, based on firm performance measured by EVA (Economic Value Added), ${ }^{13}$ the amount of PSP bonus which each employee receives is determined as a percentage of his/her monthly base salary (e.g., the last year of PSP bonus was 200 percent of base salary).

Both firms also use TIPs. For example, at a division of Firm A which we visited has two departments and each department consists of five production lines. Every month based on line performance (consisting of productivity and quality as compared to targets set by the supervisor and approved by the plant manager), one line in each department will win and receive 300,000 won. How to spend the prize monies is up to each winning line and the winning line often organizes dinner parties for all line members or save some prize monies to fund group trips to popular resorts. The team incentive pay has been in existence for at least 16 years. The supervisor we interviewed strongly believes that their TIP has been a significant motivating factor.

Firm B also has a similar TIP with two distinct differences. First, instead of awarding a prize every month, Firm B selects the winning team once a year, based on team performance. Team performance is assessed based on two criteria: (i) how high the team sets its target in productivity, quality, and cost reduction; and (ii) whether the team actually achieves the target.

${ }^{13}$ EVA is essentially after-tax operating profit minus the total cost of capital. 
Second, the prize is a three-day special training trip to a most popular and expensive resort place. For example, the firm paid for a three-day group trip to Je Ju Do (the Korean counterpart to Hawaii) for the winning team.

Like in the case of Firm A, the winner is decided by the plant managers. Members of the winning team are all excited about winning and proud of the team. Again, our informant at Firm B (HR director) believes that their TIP is a great motivator of individual workers and boosts the team spirit.

In spite of their reputation as highly participatory firms in Korea, stock-based schemes are much less developed in both firms. Firm A is a publicly-traded firm and does have an ESOP for all employees. However, our informant at Firm A (HR director) did not hesitate to reveal that the firm has not issued any new stock since 1993 and that the ESOP has been inactive. Firm A has no SOP currently while planning to introduce it to executives only next year. Firm B is not publicly traded and thus has no stock-based incentive plans.

Lastly, several scholars have suggested that different forms of alternative compensation schemes may be complementary. Weitzman and Kruse (1990) argue, for example, that PSPs work only when the free rider problem is effectively controlled. When work is done in teams and the size of teams is sufficiently small that each team member can easily observe each other's effort, TIPs can alleviate the free-rider problem. As such, PSPs and TIPs can be complements. However, considering the asymmetric penetration of PSPs and TIPs (90\% for PSPs and $60 \%$ for TIPs) in Korea, the complementarity effect of TIPs on PSPs may be limited. Our data will allow us to examine whether different forms of financial participation are complements.

\section{Productivity Effects of Financial Participation Schemes: Fixed Effect Estimates}


We follow a methodology used by Jones and Kato (1995) who provided the first systematic evidence on the productivity effects of Japanese financial participation schemes (in particular ESOPs and the Japanese bonus system). That is, we estimate Cobb-Douglas production functions with fixed effects, augmented by a dummy variable capturing the productivity effect of each employee financial participation scheme:

(2) $\ln \mathrm{Q}_{\mathrm{it}}=\beta_{\mathrm{K}} \ln \mathrm{K}_{\mathrm{it}}+\beta_{\mathrm{L}} \ln \mathrm{L}_{\mathrm{it}}+\beta_{1} \mathrm{PSP}_{\mathrm{it}-\mathrm{j}}$

$+($ firm specific fixed effects $)+($ year effects $)+($ industry time trends $)+u_{i t}$

(3) $\ln Q_{i t}=\beta_{\mathrm{K}} \ln K_{i t}+\beta_{\mathrm{L}} \ln \mathrm{L}_{\mathrm{it}}+\beta_{1} \mathrm{ESOP}_{\mathrm{it}-\mathrm{j}}$

$+($ firm specific fixed effects $)+($ year effects $)+($ industry time trends $)+u_{i t}$

(4) $\ln Q_{i t}=\beta_{K} \ln K_{i t}+\beta_{L} \ln L_{i t}+\beta_{1} S_{S O P} i t j$

$+($ firm specific fixed effects $)+($ year effects $)+($ industry time trends $)+u_{i t}$

(5) $\ln Q_{i t}=\beta_{K} \ln K_{i t}+\beta_{L} \ln L_{i t}+\beta_{1} T_{I P}$ it-j

$+($ firm specific fixed effects $)+($ year effects $)+($ industry time trends $)+u_{i t}$

where $\mathrm{Q}_{i t}$ is output of firm i in year $t ; \mathrm{K}_{i t}$ is the capital stock; $\mathrm{L}_{\mathrm{it}}$ is labor; $\mathrm{PSP}_{\mathrm{itt}}$ is a dummy variable which takes the value of 1 if PSPs have been in existence for $\mathrm{j}$ and more years, and the value of zero otherwise; $\mathrm{ESOP}_{\mathrm{it-j}}$ is a dummy variable which takes the value of 1 if ESOPs have been in existence for $\mathrm{j}$ and more years, and the value of zero otherwise; $\mathrm{SOP}_{\mathrm{it}-\mathrm{j}}$ is a dummy variable which takes the value of 1 if SOPs have been in existence for $j$ and more years, and the value of zero otherwise; $\operatorname{TIP}_{\mathrm{it}-\mathrm{j}}$ is a dummy variable which takes the value of 1 if TIPs have been in existence for $\mathrm{j}$ and more years, and the value of zero otherwise; and $\beta$ 's are slope coefficients. For the disturbance term, $\mathrm{u}_{\mathrm{it}}$, we assume $\mathrm{u}_{\mathrm{it}} \sim \operatorname{NID}\left(0, \sigma^{2}\right)$. As a robustness check, we also consider translog production functions and find that our key results (the estimated productivity effects of financial participation schemes) do not change when we consider translog production 
functions. $^{14}$

The coefficient on $\mathrm{PSP}_{-\mathrm{j}}$ (for the sake of exposition, from now on, we omit subscripts $\mathrm{i}$ and $\mathrm{t}$ ) can be interpreted as indicating the productivity difference between firms that have had PSPs for at least $\mathrm{j}$ years and firms with no PSPs. Analogous interpretations can be given to the coefficients on $\mathrm{ESOP}_{-\mathrm{j}}, \mathrm{SOP}_{-\mathrm{j}}$ and $\mathrm{TIP}_{-\mathrm{j}}$.

We allow for lags (up to three years, or $\mathrm{j}=1,2$, and 3 ) in the productivity effects of employee financial participation schemes. First, it is highly unlikely that instituting a financial participation scheme will instantly create significant interest alignment between labor and management. It takes time for the introduced scheme to generate an industrial relations climate conducive to the aforementioned positive productivity effects. ${ }^{15}$ Second, a newly established financial participation scheme may go through a significant amount of learning by doing in its early developmental years. ${ }^{16}$ Lastly, in investigating the productivity effects of employee financial participation schemes, ideally we want to use the presence of such schemes (a de jure measure) as well as the extent of employee financial participation schemes (a de facto measure), such as the penetration of such schemes to the labor force. Unfortunately, no panel data on such de facto measures are available for Korean firms. We can, however, measure the extent of employee financial participation schemes indirectly by allowing for lags in the productivity effects of employee financial participation schemes insofar as the extent of employee financial participation schemes is positively correlated with the length of time employee financial participation schemes have been in place (see Freeman and Kleiner, 2000 and Kato, 2006 for such positive correlations).

In sum, we assume that it will take at least $\mathrm{j}$ years $(\mathrm{j}=1,2$, and 3$)$ for a newly introduced

${ }^{14}$ We report the Cobb-Douglas results since the translog estimates yield an implausible (negative) distribution parameter for capital. These, and other, unreported regression results are available from the corresponding author at tkato@,colgate.edu upon request.

${ }^{15}$ For similar arguments, see Pil and MacDuffie (1996) and Ichniowski and Shaw (1995).

${ }^{16}$ See for instance Kato and Morishima (2002). 
employee financial participation scheme to mature and hence realize its full potential for creating significant interest alignment between labor and management.

We include firm specific fixed effects to capture the time-invariant unobserved heterogeneity of our firms. In particular, firm specific fixed effects will attempt to control for differences among firms in managerial abilities and worker quality. As Wadhwani and Wall (1990) argue, PSPs might be adopted in firms that are better managed. If so, the coefficients on $\mathrm{PSP}_{-\mathrm{j}}$ might indicate the effects of better managers and superior management in general as well as the actual effects of PSPs. To the extent that managerial differences across firms are time-invariant, firm specific fixed effects will help separate the two effects. Moreover, as Conte and Svejnar (1990) argue, firms with ESOPs might have more productive and more qualified workers than do conventional firms. To the extent that they are time-invariant, firm specific fixed effects will also capture these quality differences. ${ }^{17}$

In addition, we include year effects to capture technological change and other shocks that are common to all firms. Industry time trends are also included to capture industry specific time trends that are common to all firms in each of fifteen industries.

To test if having had at least one employee financial participation scheme (regardless of which scheme) results in any significant productivity gains, we create an additional variable, FPART $_{\text {it-j }}$ (a dummy variable which takes the value of 1 if at least one employee financial participation scheme has been in existence for $\mathrm{j}$ and more years, and the value of zero otherwise), and estimate:

(6) $\ln Q_{i t}=\beta_{K} \ln K_{i t}+\beta_{L} \ln L_{i t}+\beta_{1} F_{P A R T}$ it $-j$

$$
+(\text { firm specific fixed effects })+(\text { year effects })+(\text { industry time trends })+u_{i t}
$$

17 A similar argument is made for the case of profit sharing by Nakamura and Nakamura (1991) and Ehrenberg (1990). 
Table 3 provides summary statistics. Output is measured by value added deflated by the PPI for manufacturing products at the 2-digit industry level (published by the Bank of Korea) for each year. ${ }^{18}$ The capital stock is proxied by the fixed assets of the firm deflated by the PPI for capital goods (published by the Bank of Korea). Labor is measured by the number of employees. We show data for the whole sample and also disaggregated by whether or not the firm has had each employee financial participation scheme for at least one full year. The table indicates that, compared to firms without a PSP, in PSP firms on average: (i) value added is 140 percent larger; (ii) employment is 9 percent smaller; (iii) capital stock is 267 percent larger; and (iv) capital/labor ratio is 182 percent higher. Likewise, compared to firms without an ESOP, in ESOP firms on average: (i) value added is 255 percent larger; (ii) employment is 97 percent larger; (iii) capital stock is over 400 percent larger; and (iv) capital/labor ratio is 165 percent higher.

Furthermore, contrasted to firms without an SOP, in firms with SOPs on average: (i) value added is 6 percent larger; (ii) employment is 59 percent smaller; (iii) capital stock is 231 percent larger; and (iv) capital/labor ratio is 266 percent higher. Finally, compared to firms without a TIP, in firms with TIPs on average: (i) value added is 207 percent larger; (ii) employment is 9 percent smaller; (iii) capital stock is 351 percent larger; and (iv) capital/labor ratio is 253 percent higher.

Table 4A reports the OLS estimates of Eq. (2)-Eq. (6) with $\mathrm{j}=1 .{ }^{19} \quad$ The estimated coefficients on the PSP dummy and TIP dummy are positive and significant at the 5 percent level.

18 The data on value added as a proxy for $\mathrm{Q}$ were created by adding labor costs and depreciation to operational profit. A similar procedure was used to calculate value added for Japan with similar accounting practices by the Oriental Economist (Toyokeizai Shinpo Sha) whose value added data were widely used by both scholars and practitioners (e.g., Jones and Kato, 1995; Ohkusa and Ohtake, 1997; and Kato and Morishima, 2002). Most prior studies use sales to proxy output. We believe our use of the (theoretically preferable) value added instead of sales is a strength of the paper.

19 The sums of estimated $\beta_{\mathrm{K}}$ and $\beta_{\mathrm{L}}$ for the five specifications are around 0.7 , suggesting decreasing returns to scale As explained in Hsiao (1986; 26-28), the use of panel data in production function estimation leads to a smaller sum of estimated output elasticities. The sums of estimated output elasticities reported above are similar to those cited in Hsiao (1986; 27) as well as those obtained by Jones and Kato (1995) and Kato and Morishima (2002) for Japanese manufacturing firms. 
By using a simple formulae, $\left\{\exp \left(\beta_{\mathrm{E}}\right)-1\right\}^{*} 100$, the size of the productivity gains from having had a PSP for at least one full year is estimated to be 10.6 percent, and likewise, the size of the productivity gains from having had a TIP for at least one full year is estimated to be 12.2 percent.

On the other hand, the estimated coefficients on the ESOP dummy and SOP dummy are not statistically significant at the 10 percent level, suggesting no significant productivity gains from having had an ESOP or a SOP for at least one full year. It appears to matter which financial participation scheme is introduced. To confirm this, the estimated coefficient on the FPART dummy is also not statistically significant at the 10 percent level, suggesting no significant productivity gain from having had at least one financial participation scheme for one or more years with no regard to the types of financial participation schemes.

As discussed earlier, the absence of significant productivity gains from ESOPs and SOPs may be due to longer lag in the productivity effects of ESOPs and SOPs. Tables $4 \mathrm{~b}$ and $4 \mathrm{c}$ report the OLS estimates of Eq. (2) - Eq. (6) with two year lag and three year lag ( $j=2$ and 3). The tables show that the estimated coefficients on the ESOP and SOP dummy variables are still statistically insignificant at the 10 percent level, confirming that neither ESOPs not SOPs has significant impact on enterprise efficiency even after allowing for considerable gestation periods.

Tables $4 \mathrm{~b}$ and $4 \mathrm{c}$ also reveal an interesting difference in the time profiles of the productivity effects between PSPs and TIPs. The estimated coefficients on the PSP dummy continue to be statistically significant with longer lag whereas the estimated coefficient on the TIP dummy becomes substantially smaller and insignificant with three year lag. The productivity effect of TIPs may start to dissipate to some degree after three years. We have two preliminary interpretations of the different time profile of the productivity effects between PSPs and TIPs though such interpretations will probably need to be tempered somewhat until a future analysis including 
more years of data and thus more observations with TIP $=1$ will confirm them ${ }^{20}$ First, as demonstrated in our field research at Firms A and B, the size of the PSP bonus is considerably greater than that of the TIP bonus. For example, at both Firms A and B, the average PSP bonus amounts to 200 percent of monthly base pay per person while a typical TIP bonus is an overnight group trip to a resort which is definitely a non-trivial prize yet rarely amounts to two months of base pay. As Kruse (1993) shows, the size of the prize matters for the productivity effects of financial participation schemes.

Second, as we demonstrated earlier in our case reports, PSP bonuses are almost always given to each individual employee in the form of cash whereas TIP bonuses are often provided to a group of employees in the form of funding for group activities, such as group trips. It is plausible that the marginal utility of group activities diminishes more rapidly than that of cash.

We have found statistically significant productivity effects for PSPs and TIPs separately. To discern the relative importance of PSPs and TIPs in the goal alignment process, we further estimate a nested model:

(7) $\ln Q_{\text {it }}=\beta_{\mathrm{K}} \ln \mathrm{K}_{\mathrm{it}}+\beta_{\mathrm{L}} \ln \mathrm{L}_{\mathrm{it}}+\beta_{1} \mathrm{PSP}_{\mathrm{it}-\mathrm{j}}+\beta_{2} \mathrm{TIP}_{\mathrm{it}-\mathrm{j}}$

$+($ firm specific fixed effects $)+($ year effects $)+($ industry time trends $)+u_{i t}$ Furthermore, to test whether PSPs and TIPs are complements, we add the interaction term involving both PSP and TIP:

(8) $\ln Q_{i t}=\beta_{K} \ln K_{i t}+\beta_{L} \ln L_{i t}+\beta_{1} P_{S P} P_{i t-j}+\beta_{2}$ TIP $_{i t-j}+\beta_{2}\left(P_{\text {SP }}\right.$ it- $\left.* T_{\text {TIt }}\right)$ $+($ firm specific fixed effects $)+($ year effects $)+($ industry time trends $)+u_{i t}$

Table 5 shows the OLS estimates of Eq. (7) and (8). The estimated coefficients on the PSP and TIP dummy variables are statistically significant at the 10 percent level when we consider both

${ }^{20}$ Jones and Kato (2007) find similar evidence on the dissipating performance effects of employee involvement. 
variables simultaneously, pointing to the robustness of the significant productivity effects of PSPs and TIPs. When the interaction term is added, the estimated coefficients on the PSP and TIP dummy variables are statistically significant at the 5 percent level and the estimated coefficient on the interaction term is negative yet not quite statistically significant at the 10 percent level though fairly close to statistically significant. As such there is no statistically significant evidence on the complementarity between PSPs and TIPs, suggesting that the complementary role of TIPs in easing the free-rider problem of PSPs may be limited due to that fact that TIPs cover less than $60 \%$ of the labor force whereas PSPs cover over 90\%. PSPs and TIPs are more likely to be substitutes than complements.

\section{$\underline{\text { V. Conclusions }}$}

We have reported the first results for Korean firms on the effects of various employee financial participation schemes including Profit Sharing Plans (PSPs), Employee Stock Ownership Plans (ESOPs), Stock Option Plans (SOPs) and Team Incentive Plans (TIPs) by estimating production functions using a unique panel data set containing firms with and without such schemes. We have found consistently that the introduction of a PSP or a TIP will lead to a significant increase in productivity (about 10 percent) whereas we have found no such evidence for ESOPs or SOPs. Further evidence has been found that the productivity payoff appears to be more long-lasting for PSPs than for TIPs. Finally, we have failed to find any statistically significant evidence on the complementarity between PSPs and TIPs and evidence appears to suggest hat they are more likely to be substitutes.

Our findings are relevant for two broad sets of issues. First, our findings are relevant to the observation that pay systems are rapidly changing away from a fixed wage contractual payment 
basis in many parts of the world (Ben-Ner and Jones, 1992). Foremost among these changes is the explosion in the extent of various forms of alternative pay methods, especially employee financial participation schemes in western economies in recent years. However, because of the limited nature of the available data, the econometric evidence on the economic effects of changing pay systems for major corporations in developing countries and NICs is quite thin. Consequently, by using panel data with information on one of the most comprehensive lists of employee financial participation schemes, our findings provide some of the first, more reliable evidence on the important issue of the effects on productive efficiency. Furthermore, our findings of positive productivity effects of PSPs and TIPs in Korea suggest that we are likely to see further evolution of pay systems away from fixed wage contractual forms toward employee financial participation not only in mature industrialized countries but also in NICs and transition economies (notably China).

The second concerns the current public policy debate over economic reforms in Korea. Since the Asian Crisis, many policy makers and practitioners have been questioning the validity of their existing management practices and seeking new ways to improve performance of Korean firms. ${ }^{21}$ By providing rigorous evidence on what parts of the existing management practices have worked and what parts have not worked and whether complementarity exists among various practices, our paper will help policy makers and practitioners make informed decision on their current reform efforts.

21 "New ways" often mean "Anglo-American ways", such as replacing allegedly rigid internal labor markets (characterized by long-term employment, seniority-based wage, and various human resource management practices) with flexible external labor markets. See, for instance, OECD (2000). 


\section{References}

Baker, George; Gibbons, Robert and Murphy, Kevin J. "Subjective Performance Measures in Optimal Incentive Contracts." Quarterly Journal of Economics, 1994, 109(4), pp. 1125-56.

Bayo-Moriones, José Alberto; Galilea-Salvatierra, Pedro Javier and Merino-Díaz de Cerio, Javier. "Participation, Cooperatives and Performance: An Analysis of Spanish Manufacturing Firms." T. Kato and J. Pliskin, Determinants of the Incidence and the Effects of Participatory Organizations: Advances in the Economic Analysis of Participatory and Labor-Managed Firms. Amsterdam: Elsevier/JAI, 2003, 31-56.

Ben-Ner, Avner and Jones, Derek C. "Employee Participation, Ownership, and Productivity: A Theoretical Framework." Industrial Relations, 1995, 34(4), pp. 532-54.

Black, Sandra E. and Lynch, Lisa M. "How to Compete: The Impact of Workplace Practices and Information Technology on Productivity." Review of Economics and Statistics, 2001, 83(3), pp. 434-45.

. "What's Driving the New Economy? The Benefits of Workplace Innovation." Economic Journal, 2004, 114(493), pp. F97-116.

Blasi, Joseph; Conte, Michael and Kruse, Douglas. "Employee Stock Ownership and Corporate Performance among Public Companies." Industrial and Labor Relations Review, 1996, 50(1), pp. 60-79.

Blinder, Alan S., ed. Paying for Productivity: A Look at the Evidence. Washington, D.C.: Brookings Institution, 1990.

Bryson, Alex and Freeman, Richard. "How Does Shared Capitalism Affect Economic Performance in the U.K.?" National Bureau of Economic Research, Inc, NBER Working Papers: 14235, 2008.

Cin, Beom-cheol and Smith, Stephen C. "Employee Stock Ownership and Participation in South Korea: Incidence, Productivity Effects, and Prospects." Review of Development Economics, 2002, 6(2), pp. 263-83.

Conte, Michael A. and Svejnar, Jan. "The Performance Effects of Employee Ownership Plans," A. S. Blinder, Paying for Productivity: A Look at the Evidence. Washington, D.C.: 1990, 143-72.

Conyon, Martin J. and Freeman, Richard B. "Shared Modes of Compensation and Firm Performance: U.K. Evidence," D. Card, R. Blundell and R. B. Freeman, Seeking a Premier Economy: The Economic Effects of British Economic Reforms, 1980-2000. Chicago and London: University of Chicago Press, 2004, 109-46.

DeVaro, Jed. "Teams, Autonomy, and the Financial Performance of Firms." Industrial Relations, 2006, 45(2), pp. 217-69.

Doucouliagos, Chris. "Worker Participation and Productivity in Labor-Managed and Participatory Capitalist Firms: A Meta-Analysis." Industrial and Labor Relations Review, 1995, 49(1), pp. 58-77.

Ehrenberg, Ronald G. "Alternative Pay Systems, Firm Performance, and Productivity: Comment," A. S. Blinder, Paying for Productivity: A Look at the Evidence. Washington, D.C.: 1990, 88-94.

Eriksson, Tor. "The Effects of New Work Practices - Evidence from Employer-Employee Data." T. Kato and J. Pliskin, Determinants of the Incidence and the Effects of Participatory Organizations: Advances in the Economic Analysis of Participatory and Labor-Managed Firms. Amsterdam: Elsevier/JAI, 2003, 3-30. 
FitzRoy, Felix R. and Kraft, Korenelius. "Cooperation, Productivity, and Profit Sharing." Quarterly Journal of Economics, 1987, 102(1), pp. 23-35.

Freeman, Richard B. and Kleiner, Morris M. "Who Benefits Most from Employee Involvement: Firms or Workers?" American Economic Review, 2000, 90(2), pp. 219-23.

Freeman, Richard; Kleiner, Morris and Ostroff, Cheri. "The Anatomy of Employee Involvement and Its Effects on Firms and Workers," NBER Working Paper No. 8050, 2000.

Gibbons, Robert. "Incentives and Careers in Organizations," Advances in Economics and Econometrics: Theory and Applications: Seventh World Congress. Volume 2. Cambridge; New York and Melbourne: Cambridge University Press, 1997, 1-37.

Hamilton, Barton H.; Nickerson, Jack A. and Owan, Hideo. "Team Incentives and Worker Heterogeneity: An Empirical Analysis of the Impact of Teams on Productivity and Participation." Journal of Political Economy, 2003, 111(3), pp. 465-98.

Helper, Susan. "Complementarity and Cost Reduction: Evidence from the Auto Supply Industry," Working Paper No. 6033 (revised). Cambridge, MA: National Bureau of Economic Research, 1998.

Heywood, John S.; Jirjahn, Uwe and Wei, Xiangdong. "Teamwork, Monitoring and Absence." Journal of Economic Behavior \& Organization, 2008, 68(3/4), pp. 676-90.

Holmstrom, Bengt and Milgrom, Paul. "The Firm as an Incentive System." American Economic Review, 1994, 84(4), pp. 972-91.

Hsiao, Cheng. Analysis of Panel Data. Cambridge; New York and Sydney: Cambridge University Press, 1986.

Ichniowski, Casey and Shaw, Kathryn. "Old Dogs and New Tricks: Determinants of the Adoption of Productivity-Enhancing Work Practices." Brookings Papers on Economic Activity, 1995, 0(0), pp. 1-55.

Ichniowski, Casey; Shaw, Kathryn and Prennushi, Giovanna. "The Effects of Human Resource Management Practices on Productivity: A Study of Steel Finishing Lines." American Economic Review, 1997, 87(3), pp. 291-313.

Jones, Derek C. and Pliskin, Jeffrey. "The Effects of Worker Participation, Employee Ownership and Profit Sharing on Economic Performance: A Partial Review," R. Raymond and R. Veljko, Ownership and Participation: International Handbook of Participation in Organizations Vol.2. Oxford: Oxford University Press, 1991, 43-63.

Jones, Derek C.; Kalmi, Panu and Kauhanen, Antti. "Human Resource Management Policies and Productivity: New Evidence from an Econometric Case Study." Oxford Review of Economic Policy, 2006, 22(4), pp. 526-38.

. "Teams, Performance-Related Pay, Profit-Sharing and Productive Efficiency: Evidence from a Food-Processing Plant," Industrial and Labor Relations Review (forthcoming), 2009.

Jones, Derek C. and Kato, Takao. "The Impact of Teams on Output, Quality and Downtime: An Empirical Analysis Using Individual Panel Data," IZA Discussion Paper No. 2917 (forthcoming in Industrial and Labor Relations Review), 2007.

- "The Productivity Effects of Employee Stock-Ownership Plans and Bonuses: Evidence from Japanese Panel Data." American Economic Review, 1995, 85(3), pp. 391-414.

Jones, Derek C.; Kato, Takao and Pliskin, Jeffrey. "Profit Sharing and Gainsharing: A Review of Theory, Incidence and Effects," D. Lewis, D. Mitchell and M. Zaidi, The Human Resource Management Handbook Part I. Greenwich, CT: JAI Press, 1997, 153-74. 
Kandel, Eugene and Lazear, Edward P. "Peer Pressure and Partnerships." Journal of Political Economy, 1992, 100(4), pp. 801-17.

Kato, Takao. "Determinants of the Extent of Participatory Employment Practices: Evidence from Japan." Industrial Relations, 2006, 45(4), pp. 579-605.

Kato, Takao; Lee, Ju Ho; Lee, Kang-Sung and Ryu, Jang-Soo. "Employee Participation and Involvement in Korea: Evidence from a New Survey and Field Research." International Economic Journal, 2005, 19(2), pp. 251-81.

Kato, Takao and Morishima, Motohiro. "The Nature, Scope and Effects of Profit Sharing in Japan: Evidence from New Survey Data." International Journal of Human Resource Management, 2003, 14(6), pp. 942-55.

. "The Productivity Effects of Participatory Employment Practices: Evidence from New Japanese Panel Data." Industrial Relations, 2002, 41(4), pp. 487-520.

Kruse, D and Blasi, J. "Employee Ownership, Employee Attitudes, and Firm Performance," D. Lewis, D. Mitchell and M. Zaidi, The Human Resource Management Handbook Part I. Greenwich, CT: JAI Press, 1997, pp. 113-52.

Kruse, Douglas L. Profit Sharing: Does It Make a Difference? Kalamazoo, Michigan: W.E. Upjohn Institute for Employment Research, 1993.

Kruse, Douglas L.; Blasi, Joseph R. and Park, Rhokeun. "Shared Capitalism in the U.S. Economy? Prevalence, Characteristics, and Employee Views of Financial Participation in Enterprises," National Bureau of Economic Research, Inc, NBER Working Papers: $14225,2008$.

Milgrom, Paul and Roberts, John. "Complementarities and Fit: Strategy, Structure, and Organizational Change in Manufacturing." Journal of Accounting and Economics, 1995, 19(2-3), pp. 179-208.

Nakamura, Masao and Nakamura, Alice. "Risk Behavior and Determinants of Bonus Versus Regular Pay in Japan." Journal of the Japanese and International Economies, 1991, 5(2), pp. 140-59.

OECD. OECD Economic Surveys: Korea. Organisation for Economic Cooperation \& Development, 2000.

Ohkusa, Yasushi and Ohtake, Fumio. "The Productivity Effects of Information Sharing, Profit Sharing, and ESOPs." Journal of the Japanese and International Economies, 1997, 11(3), pp. 385-402.

Pil, Frits K. and MacDuffie, John Paul. "The Adoption of High-Involvement Work Practices." Industrial Relations, 1996, 35(3), pp. 423-55.

Prendergast, Canice. "The Provision of Incentives in Firms." Journal of Economic Literature, 1999, 37(1), pp. 7-63.

Sesil, James C.; Kroumova, Maya K.; Blasi, Joseph R. and Kruse, Douglas L. "Broad-Based Employee Stock Options in Us 'New Economy' Firms." British Journal of Industrial Relations, 2002, 40(2), pp. 273-94.

Wadhwani, Sushil and Wall, Martin. "The Effects of Profit-Sharing on Employment, Wages, Stock Returns and Productivity: Evidence from U.K. Micro-Data." Economic Journal, 1990, 100(399), pp. 1-17.

Zwick, Thomas. "Employee Participation and Productivity." Labour Economics, 2004, 11(6), pp. $715-40$. 
Table 1 Proportion of Publicly Traded Firms with Employee Financial Participation Schemes in Korea from 1980 to 2000

\begin{tabular}{|c|c|c|c|c|c|c|c|c|c|c|}
\hline \multirow[b]{2}{*}{ Year } & \multicolumn{2}{|c|}{$\%$ firms with PSPs ${ }^{\mathrm{a}}$} & \multicolumn{2}{|c|}{$\%$ firms with ESOPs ${ }^{b}$} & \multicolumn{2}{|c|}{$\%$ firms with SOPs } & \multicolumn{2}{|c|}{$\%$ firms with TIPs $^{\mathrm{d}}$} & \multicolumn{2}{|c|}{$\begin{array}{l}\% \text { firms with at least one } \\
\text { financial participation } \\
\text { scheme }^{\mathrm{e}}\end{array}$} \\
\hline & all & manufacturing & all & manufacturing & all & manufacturing & all & manufacturing & all & manufacturing \\
\hline 1980 & $3.18 \%$ & $3.52 \%$ & $5.92 \%$ & $4.57 \%$ & $0.00 \%$ & $0.00 \%$ & $0.00 \%$ & $0.00 \%$ & $8.94 \%$ & $7.80 \%$ \\
\hline 1981 & $3.18 \%$ & $3.52 \%$ & $5.92 \%$ & $4.57 \%$ & $0.00 \%$ & $0.00 \%$ & $0.00 \%$ & $0.00 \%$ & $8.94 \%$ & $7.80 \%$ \\
\hline 1982 & $3.18 \%$ & $3.52 \%$ & $6.54 \%$ & $5.02 \%$ & $0.00 \%$ & $0.00 \%$ & $0.00 \%$ & $0.00 \%$ & $9.60 \%$ & $8.29 \%$ \\
\hline 1983 & $3.18 \%$ & $3.52 \%$ & $6.85 \%$ & $5.02 \%$ & $0.00 \%$ & $0.00 \%$ & $0.28 \%$ & $0.42 \%$ & $9.60 \%$ & $8.29 \%$ \\
\hline 1984 & $3.18 \%$ & $3.52 \%$ & $6.85 \%$ & $5.02 \%$ & $0.00 \%$ & $0.00 \%$ & $0.28 \%$ & $0.42 \%$ & $9.60 \%$ & $8.29 \%$ \\
\hline 1985 & $3.18 \%$ & $3.52 \%$ & $8.41 \%$ & $7.31 \%$ & $0.00 \%$ & $0.00 \%$ & $0.28 \%$ & $0.42 \%$ & $10.93 \%$ & $10.24 \%$ \\
\hline 1986 & $3.47 \%$ & $3.96 \%$ & $8.72 \%$ & $7.76 \%$ & $0.00 \%$ & $0.00 \%$ & $0.28 \%$ & $0.42 \%$ & $11.26 \%$ & $10.73 \%$ \\
\hline 1987 & $3.76 \%$ & $3.96 \%$ & $12.15 \%$ & $11.42 \%$ & $0.00 \%$ & $0.00 \%$ & $0.28 \%$ & $0.42 \%$ & $13.91 \%$ & $13.66 \%$ \\
\hline 1988 & $4.34 \%$ & $4.85 \%$ & $18.07 \%$ & $17.81 \%$ & $0.00 \%$ & $0.00 \%$ & $0.28 \%$ & $0.42 \%$ & $20.53 \%$ & $20.98 \%$ \\
\hline 1989 & $4.62 \%$ & $5.29 \%$ & $19.00 \%$ & $19.18 \%$ & $0.00 \%$ & $0.00 \%$ & $0.28 \%$ & $0.42 \%$ & $21.52 \%$ & $22.44 \%$ \\
\hline 1990 & $7.80 \%$ & $9.25 \%$ & $24.92 \%$ & $25.57 \%$ & $0.00 \%$ & $0.00 \%$ & $0.28 \%$ & $0.42 \%$ & $29.80 \%$ & $31.71 \%$ \\
\hline 1991 & $8.38 \%$ & $10.13 \%$ & $27.10 \%$ & $27.40 \%$ & $0.00 \%$ & $0.00 \%$ & $0.28 \%$ & $0.42 \%$ & $31.79 \%$ & $34.15 \%$ \\
\hline 1992 & $9.25 \%$ & $11.01 \%$ & $28.35 \%$ & $28.77 \%$ & $0.00 \%$ & $0.00 \%$ & $1.40 \%$ & $1.69 \%$ & $33.77 \%$ & $36.10 \%$ \\
\hline 1993 & $10.12 \%$ & $11.45 \%$ & $29.60 \%$ & $29.68 \%$ & $0.00 \%$ & $0.00 \%$ & $1.96 \%$ & $2.12 \%$ & $35.76 \%$ & $36.59 \%$ \\
\hline 1994 & $11.56 \%$ & $12.78 \%$ & $33.33 \%$ & $33.79 \%$ & $0.00 \%$ & $0.00 \%$ & $2.52 \%$ & $2.12 \%$ & $39.74 \%$ & $40.98 \%$ \\
\hline 1995 & $13.87 \%$ & $15.86 \%$ & $37.69 \%$ & $36.99 \%$ & $0.00 \%$ & $0.00 \%$ & $4.48 \%$ & $3.81 \%$ & $45.70 \%$ & $45.37 \%$ \\
\hline 1996 & $15.03 \%$ & $17.62 \%$ & $42.06 \%$ & $40.64 \%$ & $0.00 \%$ & $0.00 \%$ & $5.32 \%$ & $4.66 \%$ & $50.99 \%$ & $49.76 \%$ \\
\hline 1997 & $16.47 \%$ & $18.06 \%$ & $47.04 \%$ & $45.21 \%$ & $0.83 \%$ & $0.83 \%$ & $6.72 \%$ & $5.93 \%$ & $55.96 \%$ & $54.15 \%$ \\
\hline 1998 & $19.65 \%$ & $21.15 \%$ & $47.66 \%$ & $45.66 \%$ & $2.22 \%$ & $2.50 \%$ & $12.61 \%$ & $11.86 \%$ & $59.27 \%$ & $57.56 \%$ \\
\hline 1999 & $30.92 \%$ & $28.19 \%$ & $52.02 \%$ & $50.68 \%$ & $7.76 \%$ & $6.67 \%$ & $19.33 \%$ & $18.64 \%$ & $69.87 \%$ & $68.29 \%$ \\
\hline 2000 & $35.84 \%$ & $32.16 \%$ & $52.34 \%$ & $51.14 \%$ & $14.96 \%$ & $12.50 \%$ & $23.25 \%$ & $19.92 \%$ & $71.52 \%$ & $69.76 \%$ \\
\hline
\end{tabular}

Source: Survey on Human Resources Management (SHRM)

${ }^{\mathrm{a}}$ Based on 346 firms (227 firms in manufacturing) who provided information on their use of PSPs (Profit Sharing Plans).

${ }^{b}$ Based on 321 firms (219 firms in manufacturing) who provided information on their use of ESOPs (Employee Stock Ownership Plans).

${ }^{c}$ Based on 361 firms (240 firms in manufacturing) who provided information on their use of SOPs (Stock Option Plans).

${ }^{\text {d. }}$ Based on 357 firms (236 firms in manufacturing) who provided information on their use of TIPs (Team Incentive Plans).

e. Based on 302 firms (205 firms in manufacturing) who provided information on their use of PSPs, ESOPs, SOPs and TIPs. 
Table 2 Percentage employees covered by each plan

\begin{tabular}{|c|c|c|c|}
\hline & $\mathrm{N}$ & Mean & S.D. \\
\hline PSPs & 133 & $90.46 \%$ & 24.19 \\
\hline ESOPs & 138 & $29.41 \%$ & 38.19 \\
\hline SOPs & 31 & $25.88 \%$ & 34.00 \\
\hline TIPs & 65 & $57.26 \%$ & 34.23 \\
\hline
\end{tabular}

Source: Survey on Human Resources Management (SHRM) 
Table 3 Summary Statistics

\begin{tabular}{|c|c|c|c|c|c|}
\hline & & $\begin{array}{l}\text { Value added in } \\
\text { billions of year } \\
2000 \text { won } \\
\left(Q^{*} 10^{9}\right)\end{array}$ & $\begin{array}{l}\text { Employment } \\
\text { (L) }\end{array}$ & $\begin{array}{l}\text { Capital stock in } \\
\text { billions of year } \\
2000 \text { won } \\
\left(\mathrm{K}^{*} 10^{9}\right)\end{array}$ & $\begin{array}{l}\text { Capital/labor } \\
\text { ratio }\left(K^{*} 10^{9} / \mathrm{L}\right)\end{array}$ \\
\hline $\begin{array}{l}\text { All observations } \\
\mathrm{N}=1974\end{array}$ & $\begin{array}{l}\text { Mean } \\
\text { S.D. }\end{array}$ & \begin{tabular}{l|}
107.43 \\
364.47 \\
\end{tabular} & $\begin{array}{l}1605.84 \\
4109.28 \\
\end{array}$ & $\begin{array}{r}3437.14 \\
12596.98 \\
\end{array}$ & \begin{tabular}{l||}
1.73 \\
2.25 \\
\end{tabular} \\
\hline $\begin{array}{l}\mathrm{PSP}_{-1}=1 \\
\mathrm{~N}=283\end{array}$ & $\begin{array}{l}\text { Mean } \\
\text { S.D. }\end{array}$ & $\begin{array}{l}211.13 \\
665.30\end{array}$ & $\begin{array}{l}1487.43 \\
3257.42\end{array}$ & $\begin{array}{r}7261.10 \\
23127.88\end{array}$ & \begin{tabular}{l||}
2.78 \\
3.74
\end{tabular} \\
\hline $\begin{array}{l}\mathrm{PSP}_{-1}=0 \\
\mathrm{~N}=1511\end{array}$ & $\begin{array}{l}\text { Mean } \\
\text { S.D. }\end{array}$ & $\begin{array}{r}88.01 \\
269.58 \\
\end{array}$ & $\begin{array}{l}1628.01 \\
4250.43\end{array}$ & $\begin{array}{l}2720.93 \\
9234.46 \\
\end{array}$ & \begin{tabular}{l||}
1.530 \\
1.777 \\
\end{tabular} \\
\hline $\begin{array}{l}\mathrm{ESOP}_{-1}=1 \\
\mathrm{~N}=731\end{array}$ & $\begin{array}{l}\text { Mean } \\
\text { S.D. }\end{array}$ & $\begin{array}{l}187.02 \\
555.77\end{array}$ & $\begin{array}{l}2267.06 \\
6143.38\end{array}$ & $\begin{array}{r}6194.15 \\
18954.77\end{array}$ & \\
\hline $\begin{array}{l}\mathrm{ESOP}_{-1}=0 \\
\mathrm{~N}=1063\end{array}$ & $\begin{array}{l}\text { Mean } \\
\text { S.D. } \\
\end{array}$ & $\begin{array}{l}52.70 \\
67.77 \\
\end{array}$ & $\begin{array}{l}151.13 \\
1434.87 \\
\end{array}$ & $\begin{array}{l}1541.20 \\
3480.66 \\
\end{array}$ & \\
\hline $\begin{array}{l}\mathrm{SOP}_{-1}=1 \\
\mathrm{~N}=18\end{array}$ & $\begin{array}{l}\text { Mean } \\
\text { S.D. } \\
\end{array}$ & \begin{tabular}{l|}
114.23 \\
352.71 \\
\end{tabular} & $\begin{array}{r}660.39 \\
1010.73 \\
\end{array}$ & $\begin{array}{r}7841.21 \\
27936.48 \\
\end{array}$ & \\
\hline $\begin{array}{l}\mathrm{SOP}_{-1}=0 \\
\mathrm{~N}=1776\end{array}$ & $\begin{array}{l}\text { Mean } \\
\text { S.D. }\end{array}$ & $\begin{array}{l}107.36 \\
364.68 \\
\end{array}$ & $\begin{array}{l}1615.42 \\
4127.77 \\
\end{array}$ & $\begin{array}{r}3392.50 \\
12353.94 \\
\end{array}$ & $\begin{array}{l}1.70 \\
2.13 \\
\end{array}$ \\
\hline $\begin{array}{l}\mathrm{TIP}_{-1}=1 \\
\mathrm{~N}=85\end{array}$ & $\begin{array}{l}\text { Mean } \\
\text { S.D. }\end{array}$ & $\begin{array}{l}300.00 \\
596.73 \\
\end{array}$ & $\begin{array}{l}1462.76 \\
1730.19\end{array}$ & $\begin{array}{l}10792.54 \\
24161.94\end{array}$ & $\begin{array}{l}4.08 \\
5.39\end{array}$ \\
\hline $\begin{array}{l}\mathrm{TIP}_{-1}=0 \\
\mathrm{~N}=1709\end{array}$ & $\begin{array}{l}\text { Mean } \\
\text { S.D. }\end{array}$ & $\begin{array}{r}97.85 \\
346.40 \\
\end{array}$ & $\begin{array}{l}1612.95 \\
4192.64 \\
\end{array}$ & $\begin{array}{r}3071.30 \\
11620.81 \\
\end{array}$ & $\begin{array}{l}1.61 \\
1.90 \\
\end{array}$ \\
\hline $\begin{array}{l}\text { FPART }_{-1}=1 \\
\mathrm{~N}=870\end{array}$ & $\begin{array}{l}\text { Mean } \\
\text { S.D. }\end{array}$ & $\begin{array}{l}164.68 \\
512.81\end{array}$ & $\begin{array}{l}2010.95 \\
5668.36\end{array}$ & $\begin{array}{r}5416.03 \\
17482.62\end{array}$ & $\begin{array}{l}2.21 \\
2.77\end{array}$ \\
\hline $\begin{array}{l}\text { FPART }_{-1}=0 \\
N=924\end{array}$ & $\begin{array}{l}\text { Mean } \\
\text { S.D. }\end{array}$ & $\begin{array}{l}53.53 \\
66.72\end{array}$ & $\begin{array}{l}1224.40 \\
1500.58\end{array}$ & $\begin{array}{l}1573.89 \\
3650.87\end{array}$ & $\begin{array}{l}1.28 \\
1.48 \\
\end{array}$ \\
\hline
\end{tabular}

Source: Survey on Human Resources Management (SHRM) and corporate proxy statement data from KLCA (Korea Listed Companies Association)

${ }^{a} \mathrm{PSP}_{-1}$ is a dummy variable which takes the value of 1 if PSPs have been in existence for at least one year, and the value of zero otherwise. Likewise, $\mathrm{ESOP}_{-1}$ is a dummy variable which takes the value of 1 if ESOPs have been in existence for at least one year, and the value of zero otherwise; $\mathrm{SOP}_{-1}$ is a dummy variable which takes the value of 1 if SOPs have been in existence for at least one year, and the value of zero otherwise; TIP -1 is a dummy variable which takes the value of 1 if TIPs have been in existence for at least one year, and the value of zero otherwise; and FPART ${ }_{-1}$ is a dummy variable which takes the value of 1 if at least one of the above four financial participation schemes has been in existence for at least one year, and the value of zero otherwise.

${ }^{b}$ For all regressions, there were 1794 observations on 205 firms over the 1990-2000 time period. All models include firm specific fixed effects, year effects and industry time trends. 
Table 4a Fixed-Effect Estimates of Cobb-Douglas Production Functions, Augmented by Financial Participation Schemes with $\mathrm{j}=1$ (Dependent Variable $=\ln Q$ )

\begin{tabular}{|c|c|c|c|c|c|c|c|c|c|c|}
\hline & \begin{tabular}{|l} 
Parameter \\
Estimates
\end{tabular} & $\begin{array}{l}\text { Value of } \mathrm{t} \\
\text { statistics }\end{array}$ & $\begin{array}{l}\text { Parameter } \\
\text { Estimates }\end{array}$ & $\begin{array}{l}\text { Value of } \mathrm{t} \\
\text { statistics }\end{array}$ & $\begin{array}{l}\text { Parameter } \\
\text { Estimates }\end{array}$ & $\begin{array}{l}\text { Value of } \mathrm{t} \\
\text { statistics }\end{array}$ & $\begin{array}{l}\text { Parameter } \\
\text { Estimates }\end{array}$ & $\begin{array}{l}\text { Value of } \mathrm{t} \\
\text { statistics }\end{array}$ & $\begin{array}{l}\text { Parameter } \\
\text { Estimates }\end{array}$ & $\begin{array}{l}\text { Value of t } \\
\text { statistics }\end{array}$ \\
\hline $\ln K$ & $0.112 * * *$ & 3.509 & $0.118 * * *$ & 3.699 & $0.116^{* * *}$ & 3.650 & $0.110 * * *$ & 3.460 & $0.117 * * *$ & 3.670 \\
\hline $\ln L$ & $0.569 * * *$ & 14.152 & $0.570 * * *$ & 14.154 & $0.568 * * *$ & 14.101 & $0.566 * * *$ & 14.066 & $0.567 * * *$ & 14.083 \\
\hline $\mathrm{PSP}_{-1}$ & $0.106 * *$ & 2.204 & & & & & & & & \\
\hline $\mathrm{ESOP}_{-1}$ & & & -0.054 & -1.287 & & & & & & \\
\hline $\mathrm{SOP}_{-1}$ & & & & & 0.036 & 0.347 & & & & \\
\hline $\mathrm{TIP}_{-1}$ & & & & & & & $0.122 * *$ & 2.199 & & \\
\hline FPART $_{-1}$ & & & & & & & & & 0.029 & 0.776 \\
\hline Adjusted $\mathrm{R}^{2}$ & \multicolumn{2}{|l|}{0.928} & \multicolumn{2}{|l|}{0.928} & \multicolumn{2}{|l|}{0.928} & \multicolumn{2}{|l|}{0.928} & \multicolumn{2}{|l|}{0.928} \\
\hline
\end{tabular}

Source: Survey on Human Resources Management (SHRM) and corporate proxy statement data from KLCA (Korea Listed Companies Association)

${ }^{a} \mathrm{PSP}_{-1}$ is a dummy variable which takes the value of 1 if PSPs have been in existence for at least one year, and the value of zero otherwise. Likewise, ESOP $_{-1}$ is a dummy variable which takes the value of 1 if ESOPs have been in existence for at least one year, and the value of zero otherwise; SOP $_{-1}$ is a dummy variable which takes the value of 1 if SOPs have been in existence for at least one year, and the value of zero otherwise; TIP ${ }_{-1}$ is a dummy variable which takes the value of 1 if TIPs have been in existence for at least one year, and the value of zero otherwise; and FPART ${ }_{-1}$ is a dummy variable which takes the value of 1 if at least one of the above four financial participation schemes has been in existence for at least one year, and the value of zero otherwise.

${ }^{\mathrm{b}}$ For all regressions, there were 1794 observations on 205 firms over the 1990-2000 time period. All models include firm specific fixed effects, year effects and industry time trends.

* Significant at the 10 percent level; ** Significant at the 5 percent level; *** Significant at the 1 percent level. 
Table 4b Fixed-effect Estimates of Cobb-Douglas Production Functions, Augmented by Financial Participation Schemes with $\mathrm{j}=2$ (Dependent Variable $=\ln Q$ )

\begin{tabular}{|c|c|c|c|c|c|c|c|c|c|c|}
\hline & $\begin{array}{l}\text { Parameter } \\
\text { Estimates }\end{array}$ & $\begin{array}{l}\text { Value of t } \\
\text { statistics }\end{array}$ & $\begin{array}{l}\text { Parameter } \\
\text { Estimates }\end{array}$ & $\begin{array}{l}\text { Value of } \\
t \text { statistics }\end{array}$ & $\begin{array}{l}\text { Parameter } \\
\text { Estimates }\end{array}$ & $\begin{array}{l}\text { Value of t } \\
\text { statistics }\end{array}$ & $\begin{array}{l}\text { Parameter } \\
\text { Estimates }\end{array}$ & $\begin{array}{l}\text { Value of } \mathrm{t} \\
\text { statistics }\end{array}$ & $\begin{array}{l}\text { Parameter } \\
\text { Estimates }\end{array}$ & $\begin{array}{l}\text { Value of } \\
\text { statistics }\end{array}$ \\
\hline $\ln K$ & 0.113 **** & 3.559 & $0.117 * * *$ & 3.680 & $0.117 * * *$ & 3.679 & $0.112 * * *$ & 3.521 & $0.117 * * *$ & 3.675 \\
\hline $\ln L$ & $0.569 * * *$ & 14.146 & $0.568 * * *$ & 14.097 & $0.568 * * *$ & 14.103 & $0.567 * * *$ & 14.076 & $0.568 * * *$ & 14.096 \\
\hline $\mathrm{PSP}_{-2}$ & $0.093 *$ & 1.723 & & & & & & & & \\
\hline $\mathrm{ESOP}_{-2}$ & & & -0.008 & -0.205 & & & & & & \\
\hline $\mathrm{SOP}_{-2}$ & & & & & -0.053 & -0.338 & & & & \\
\hline TIP $_{-2}$ & & & & & & & $0.120 *$ & 1.680 & & \\
\hline FPART $_{-2}$ & & & & & & & & & 0.045 & 1.215 \\
\hline Adjusted $\mathrm{R}^{2}$ & \multicolumn{2}{|l|}{0.928} & \multicolumn{2}{|l|}{0.928} & \multicolumn{2}{|l|}{0.928} & \multicolumn{2}{|l|}{0.928} & \multicolumn{2}{|l|}{0.928} \\
\hline
\end{tabular}

Source: Survey on Human Resources Management (SHRM) and corporate proxy statement data from KLCA (Korea Listed Companies Association)

${ }^{a} \mathrm{PSP}_{-2}$ is a dummy variable which takes the value of 1 if PSPs have been in existence for at least two years, and the value of zero otherwise. Likewise, $\mathrm{ESOP}_{-2}$ is a dummy variable which takes the value of 1 if ESOPs have been in existence for at least two years, and the value of zero otherwise; $\mathrm{SOP}_{-2}$ is a dummy variable which takes the value of 1 if SOPs have been in existence for at least two years, and the value of zero otherwise; TIP ${ }_{-2}$ is a dummy

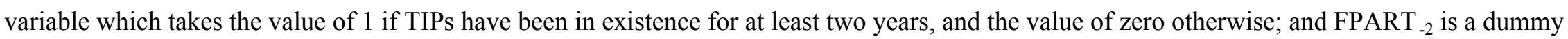
variable which takes the value of 1 if at least one of the above four financial participation schemes has been in existence for at least two years, and the value of zero otherwise.

${ }^{\mathrm{b}}$ For all regressions, there were 1794 observations on 205 firms over the 1990-2000 time period. All models include firm specific fixed effects, year effects and industry time trends.

* Significant at the 10 percent level; ** Significant at the 5 percent level; ***Significant at the 1 percent level. 
Table 4c Fixed-effect Estimates of Cobb-Douglas Production Functions, Augmented by Financial Participation Schemes with $\mathrm{j}=3$

(Dependent Variable $=\ln Q)$

\begin{tabular}{|c|c|c|c|c|c|c|c|c|c|c|}
\hline & $\begin{array}{l}\text { Parameter } \\
\text { Estimates }\end{array}$ & $\begin{array}{l}\text { Value of } t \\
\text { statistics }\end{array}$ & $\begin{array}{l}\text { Parameter } \\
\text { Estimates }\end{array}$ & $\begin{array}{l}\text { Value of } \\
\text { t statistics }\end{array}$ & $\begin{array}{l}\text { Parameter } \\
\text { Estimates }\end{array}$ & $\begin{array}{l}\text { Value of t } \\
\text { statistics }\end{array}$ & $\begin{array}{l}\text { Parameter } \\
\text { Estimates }\end{array}$ & $\begin{array}{l}\text { Value of } t \\
\text { statistics }\end{array}$ & $\begin{array}{l}\text { Parameter } \\
\text { Estimates }\end{array}$ & $\begin{array}{l}\text { Value of } \\
\text { statistics }\end{array}$ \\
\hline $\ln K$ & $0.112 * * *$ & 3.531 & $0.117 * * *$ & 3.691 & $0.117 * * *$ & 3.679 & $0.115 * * *$ & 3.601 & $0.116 * * *$ & 3.654 \\
\hline $\ln L$ & $0.570 * * *$ & 14.179 & $0.569 * * *$ & 14.110 & $0.568 * * *$ & 14.101 & $0.568 * * *$ & 14.105 & $0.568 * * *$ & 14.107 \\
\hline $\mathrm{PSP}_{-3}$ & $0.135 * *$ & 2.399 & & & & & & & & \\
\hline $\mathrm{ESOP}_{-3}$ & & & -0.018 & -0.489 & & & & & & \\
\hline $\mathrm{SOP}_{-3}$ & & & & & 0.047 & 0.175 & & & & \\
\hline TIP $_{-3}$ & & & & & & & 0.042 & 0.438 & & \\
\hline FPART $_{-3}$ & & & & & & & & & 0.019 & 0.541 \\
\hline Adjusted $\mathrm{R}^{2}$ & \multicolumn{2}{|l|}{0.928} & \multicolumn{2}{|l|}{0.928} & \multicolumn{2}{|l|}{0.928} & \multicolumn{2}{|l|}{0.928} & \multicolumn{2}{|l|}{0.928} \\
\hline
\end{tabular}

Source: Survey on Human Resources Management (SHRM) and corporate proxy statement data from KLCA (Korea Listed Companies Association)

${ }^{a} \mathrm{PSP}_{-3}$ is a dummy variable which takes the value of 1 if PSPs have been in existence for at least two years, and the value of zero otherwise. Likewise, $\mathrm{ESOP}_{-3}$ is a dummy variable which takes the value of 1 if ESOPs have been in existence for at least two years, and the value of zero otherwise; $\mathrm{SOP}_{-3}$ is a dummy variable which takes the value of 1 if SOPs have been in existence for at least two years, and the value of zero otherwise; TIP ${ }_{-3}$ is a dummy

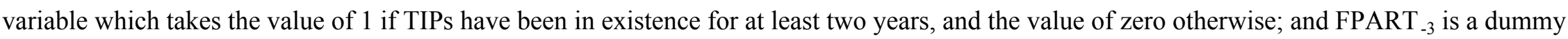
variable which takes the value of 1 if at least one of the above four financial participation schemes has been in existence for at least two years, and the value of zero otherwise.

${ }^{\mathrm{b}}$ For all regressions, there were 1794 observations on 205 firms over the 1990-2000 time period. All models include firm specific fixed effects, year effects and industry time trends.

* Significant at the 10 percent level; ** Significant at the 5 percent level; ***Significant at the 1 percent level. 
Table 5 Fixed-effect Estimates of Cobb-Douglas Production Functions (Considering both PSPs and TIPs simultaneously):

(Dependent Variable $=\ln Q)$

\begin{tabular}{||l||r|r|l|l||}
\hline \multicolumn{1}{|l||}{} & $\begin{array}{l}\text { Parameter } \\
\text { Estimates }\end{array}$ & $\begin{array}{l}\text { Value of } \mathrm{t} \\
\text { statistics }\end{array}$ & $\begin{array}{l}\text { Parameter } \\
\text { Estimates }\end{array}$ & $\begin{array}{l}\text { Value of } \mathrm{t} \\
\text { statistics }\end{array}$ \\
\hline $\ln \mathrm{0}$ & $0.107 * * *$ & 3.340 & $0.109 * * *$ & 3.409 \\
$\operatorname{lnL}$ & $0.567 * * *$ & 14.110 & $0.564 * * *$ & 14.015 \\
$\mathrm{PSP}_{-1}$ & $0.092 *$ & 1.904 & $0.121 * *$ & 2.326 \\
$\mathrm{TIP}_{-1}$ & $0.106 *$ & 1.898 & $0.160 * *$ & 2.421 \\
$\mathrm{PSP}_{-1} * \mathrm{TIP}_{-1}$ & & & -0.153 & -1.527 \\
\hline Adjusted R $^{2}$ & 0.928 & & 0.928 & \\
\hline
\end{tabular}

Source: Survey on Human Resources Management (SHRM) and corporate proxy statement data from KLCA (Korea Listed Companies Association)

${ }^{a} \mathrm{PSP}_{-1}$ is a dummy variable which takes the value of 1 if PSPs have been in existence for at least one year, and the value of zero otherwise. Likewise, ESOP ${ }_{-1}$ is a dummy variable which takes the value of 1 if ESOPs have been in existence for at least one year, and the value of zero otherwise; $\mathrm{SOP}_{-1}$ is a dummy variable which takes the value of 1 if SOPs have been in existence for at least one year, and the value of zero otherwise; TIP ${ }_{-1}$ is a dummy variable which takes the value of 1 if TIPs have been in existence for at least one year, and the value of zero otherwise; and FPART -1 is a dummy variable which takes the value of 1 if at least one of the above four financial participation schemes has been in existence for at least one year, and the value of zero otherwise.

${ }^{b}$ For all regressions, there were 1794 observations on 205 firms over the 1990-2000 time period. All models include firm specific fixed effects, year effects and industry time trends.

* Significant at the 10 percent level; ** Significant at the 5 percent level; ***Significant at the 1 percent level. 
Figure 1 Diffusion of Financial Participation Schemes among Publicly Traded Firms in Korea: 1980-2000
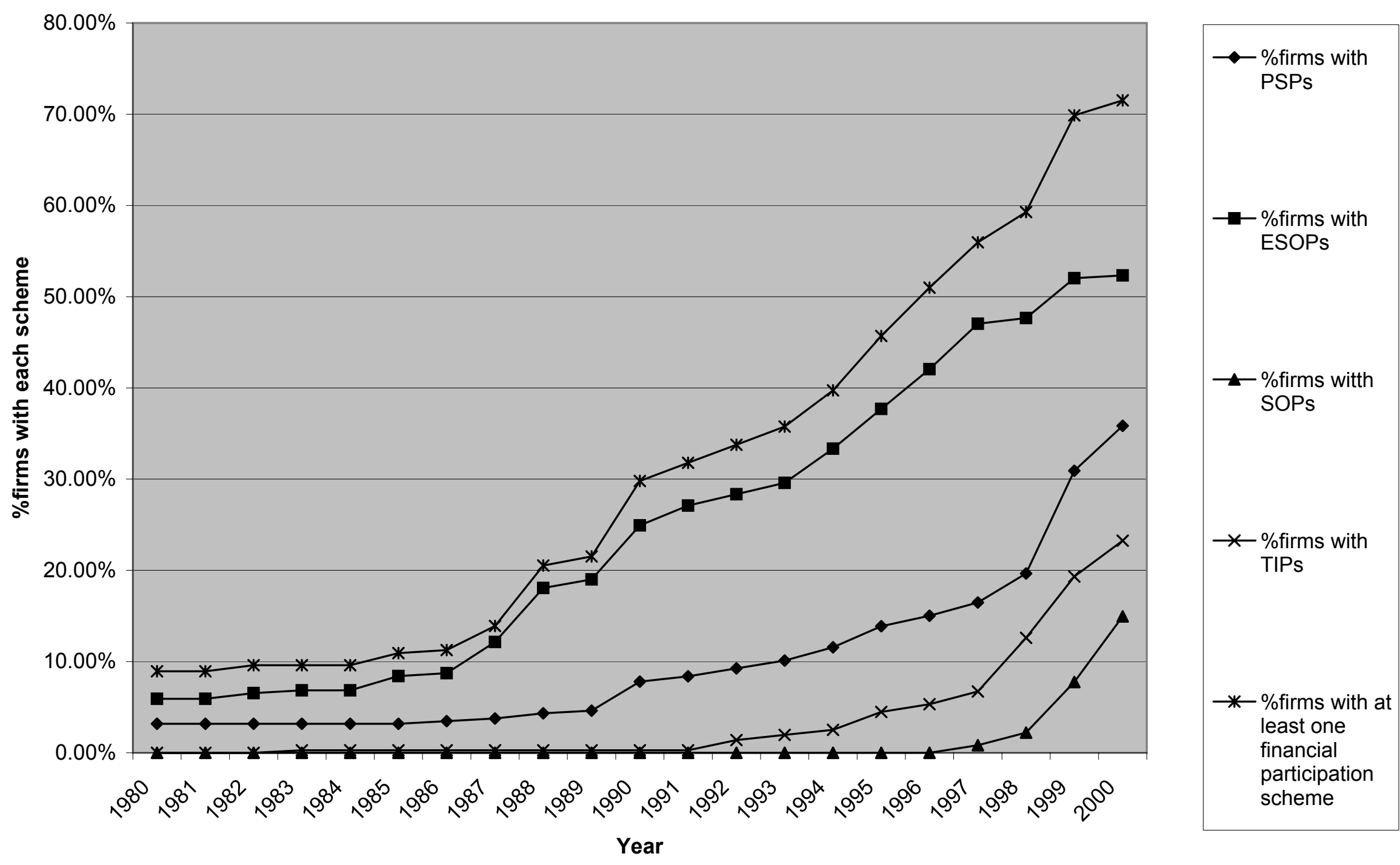